\title{
POTĘPIENIE BAEWOCHWALSTWA NA SYNODACH W TOLEDO (VI-VII WIEK)
}

\section{KONTEKST HISTORYCZNY}

Proces chrystianizacji Hiszpanii, rozpoczęty już w I wieku, od samego początku napotykal na dość poważne trudności, spośród których wymienia się m.in. silne przywiązanie ludności wiejskiej do tradycji pogańskiej ${ }^{1}$. I choć kolejne wieki świadczą o bardzo owocnej pracy misyjnej Kościoła, to jednak ciągle jeszcze, przede wszystkim na terenach wiejskich, przetrwały zwyczaje pogańskie. Problem musiał być na tyle poważny, że podejmowali go uczestnicy wielu zwoływanych synodów. Na synodzie w Elwirze odbytym na początku wieku IV grzech idolatrii został nazwany najcięższym grzechem, jaki może popełnić chrześcijanin (crimen principale) ${ }^{2}$. Dyskutowano tu o praktykach bałwochwalczych wśród chrześcijan, ale również rozważano zasady wspólistnienia chrześcijan i pogan ${ }^{3}$. Na II synodzie w Bradze, zwołanym w 572 r., podobnie jak uczyniono to w Elwirze, umieszczono idolatrię na pierwszym miejscu w katalogu grzechów śmiertelnych ${ }^{4}$. Ponadto ojcowie synodalni nakazali wprowadzenie intensywnej katechizacji ludności wiejskiej, celem wykorzenienia pozostalości wszelkich zwyczajów pogańskich ${ }^{5}$. Wspaniałym przykładem takiej katechezy jest zachowane do dzisiaj kazanic De correctione rusticorum Marcina $\mathrm{z}$ Bragi ${ }^{6}$. Istotnym wydarzeniem dla rozwoju i działalności Kościoła katolickiego w Hiszpanii i zachowania jedności wiary był III synod

${ }^{1}$ Por. M. Tuñón de Lara - J. Baldeón Baruque - A. Domínguez Ortiz, Historia Hiszpanii, thum. Sz. Jędrusiak, Kraków 1997, 48.

${ }^{2}$ Por. Concilium Eliberitanum can. 1, Mansi II 5-6; D. Ramos-Lisson, Los concilios hispanicos antes de Recaredo, w: J. Orlandis - D. Ramos-Lisson, Historia de los concilios de la España romana y visigoda, Pamplona 1986, 36.

${ }^{3}$ Por. P.C. Díaz - J.M. Torres, Pervivencias paganas en el cristianismo hispano (siglos IV-VII), w: Revisiones de Historia Antigua. El cristianismo. Aspectos históricos de su origen y difusión en Hispania, Vitoria 2000, 237.

\footnotetext{
${ }^{4}$ Por. II Concilium Bracarense can. 1, Mansi IX 838.

${ }^{5}$ Por. tamże.

${ }^{6}$ Marcin z Bragi przewodniczył obradom II synodu w Bradze.
} 
w Toledo. Zwolał go w 589 r., w dwa lata po swojej konwersji z arianizmu na katolicyzm, wizygocki król Rekkared (586-601). Kronikarz tamtego czasu, Jan z Biklar przyrównuje działalność wizygockiego władcy do zwołujących w trosce o czystość wiary sobory w Nicei i Chalcedonie rzymskich cesarzy Konstantyna Wielkiego i Marcjana ${ }^{7}$. Od III synodu w Toledo drogi i cele monarchii i Kościoła katolickiego w Hiszpanii zeszły się, podążając w wielu sprawach w tym samym kierunku ${ }^{8}$. Synody w Toledo miały ogromne znaczenie zarówno dla życia eklezjalnego, jak i politycznego królestwa. Odbywały się przecież w stolicy państwa Wizygotów, a także w stolicy najważniejszej metropolii Kościoła katolickiego na Półwyspie Iberyjskim, która zyska sobie miano prymasostwa ${ }^{9}$. Uchwały synodalne były więc egzekwowane w praktyce nie tylko przez władze kościelne, ale również przez urzędników państwowych ${ }^{10}$. W edykcie zatwierdzającym uchwały III synodu w Toledo Rekkared stwierdzit: „Niech nikt nie waży się gardzić tym, co zostało postanowione na tym świętym synodzie, niech nikt się nie ośmieli tego przekroczyć [...]. To wszystko ma moc prawną dla duchownych, dla świeckich i dla każdego człowieka" "11. Wydaje się, że po III synodzie w Toledo, Królestwo Wizygotów rządzone przez katolickiego monarchę zmierzało pewnie do stworzenia państwa religijnie jednorodnego. Proces ten przebiegał zgodnie z przyjętymi założeniami, co wyrażało się bardzo zdecydowanymi wystąpieniami przeciwko Żydom, wszelkiego rodzaju heretykom, przede wszystkim arianom, a także bałwochwalcom. Jaskrawym przykładem takich działań było wiele uchwał wspomnianego już III synodu w Toledo, jak chociażby 14 kanon, który nakazywał przymusowy chrzest dzieci zrodzonych ze związków żydowsko - chrześcijańskich. Uważa się, że był to pierwszy w historii Kościoła przypadek uchwały synodu kościelnego zmuszającej do przyjęcia chrztu $^{12}$. Należy tu wspomnieć, że na kolejnym IV synodzie w Toledo, z pew-

${ }^{7}$ Por. Joannes Biclarensis, Chronicon. Anno VIII Mauricii, PL 72, 869; zob. także J. Orlandis, La Iglesia en la España visigotica y medieval, Pamplona 1976, 35-36; J. Fontaine, Conversion et culture chez les Wisigoths d'Espagne, w: La conversione al Cristianesimo nell'Europa dell'Alto Medioevo, Spoleto 1967, 109-112; J.N. Hillgarth, La coversión de los visigodos, „Analecta Sacra Tarraconensia" 34 (1961) 21-46.

8 Por. P.C. Díaz - J.M. Torres, Pervivencias, dz. cyt., s. 242.

${ }^{9}$ Por. J. Orlandis, Los concilios en el reino visigodo católico, w: J. Orlandis - D. RamosLisson, Historia de los concilios de la España romana y visigoda, Pamplona 1986, 165-167; J.F. Rivera Recio, Encumbramiento de la Sede toledana durante la dominación visigotica, w: Hispania Sacra, VIII, Madrid 1955, 3-34. Należy zauważyć, że apogeum centralizacji Kościoła katolickiego w królestwie Wizygotów przypada na rok 687 , kiedy to biskup Toledo uzyskał wszelkie uprawnienia patriarchy i dlatego był głową calego Kościoła hiszpańskiego, zob. J. Orlandis, La Iglesia, dz. cyt., s. 93.

${ }^{10}$ Por. III Concilium Toletanum can. 18; zob. także J. Orlandis, La Iglesia, dz. cyt., s. 179-180.

11 Edictum regis de confirmatione III Concilii Toletani, Mansi IX 999-1000, thum. za: Historia chrześcijaństwa. Biskupi, mnisi, cesarze 610-1054, red. G. Dagron - P. Richè - A. Vauchez, IV, Warszawa 1999, 495-496.

${ }^{12}$ Por. J. Strzelczyk, Goci-rzeczywistośc i legenda, Warszawa 1984, 225. 
nością pod wpływem działalności św. Izydora z Sewilli, został uchwalony kanon potępiający wymuszone konwersje ${ }^{13}$, co jednak nie przeszkodziło w zatwierdzeniu na XII i XIII synodzie 28 antyżydowskich praw przygotowanych i opracowanych przez króla Erwiga $(687-702)^{14}$. Kolejne synody w Toledo podjęły się także rozwiązania kwestii bałwochwalstwa, które według informacji zawartej w 16 kanonie III synodu, rozprzestrzeniło się bardzo w Galii i na Półwyspie Iberyjskim ${ }^{15}$.

Przedmiotem naszej analizy będą ustalenia dotyczące bałwochwalstwa podjęte na synodach w Toledo w katolickim okresie królestwa Wizygotów, tzn. od 593 r. aż do najazdu Maurów i upadku królestwa, tj. do 711 roku. Ustawy dotyczące bałwochwalstwa zostały podjęte na następujących synodach w Toledo: III synod zwolany w $589 \mathrm{r}$. - kanon $16^{16}$, IV synod odbyty w $633 \mathrm{r}$. - kanon $29^{17}$, na XII synod zebrany w 681 r. - kanon $11^{18}$ oraz na XVI synod, który obradowal w $693 \mathrm{r}$. - kanon $2^{19}$. Na podstawie treści wymienionych kanonów postaramy się ukazać rodzaje uprawianego bałwochwalstwa, a także określić typ ludzi, którzy oddawali się tym praktykom. Przybliżymy również terminologię, której używali redaktorzy kanonów, by podkreślić zło idolatrii, a także zamieszczoną w kanonach argumentację biblijną. Wreszcie ukażemy przewidziane przez synody sankcje karne grożące bałwochwalcom.

\section{PRAKTYKI BAŁWOCHWALCZE}

Ojcowie synodalni w zapisach kanonów pozostawili nam swoisty katalog praktyk bałwochwalczych spotykanych w VI i VII wieku. Co prawda III synod w Toledo informuje tylko bardzo ogólnie, ze na terenach Hiszpanii i Galii spotkać można bardzo liczne przykłady praktyk bałwochwalczych, ale już uchwały kolejnego, IV synodu mówią o poradach, jakie duchowni wszelkich stopni hierarchicznych zaciągali prawdopodobnie u magów, czarowników, wróżbitów, czy jasnowidzów ${ }^{20}$. Uchwały XII i XIV synodu opisują formy kultu idoli, wspominając o adorujących kamienie, źródła i drzewa, oraz o zapalają-

${ }^{13}$ Por. IV Concilium Toletanum can. 57, Mansi X 633; zob. J. Orlandis, Los concilios en el reino visigodo catolico, w: J. Orlandis - D. Ramos-Lisson, Historia, dz. cyt., s. 288-292; J. Strzelczyk, dz. cyt., s. 233-235; J. Orlandis, Estudios de la historia eclesiástica visigoda, Pamplona 1998, 154-155.

${ }^{14}$ Por. XII Concilium Toletanum can. 9, Mansi XI 1035-1036; XIII Concilium Toletanum can. 9, Mansi XI 1071; zob. J. Strzelczyk, dz. cyt., s. 250.

${ }^{15}$ Por. J. Orlandis, Los concilios en el reino visigodo catolico, w: J. Orlandis - D. RamosLissón, Historia, dz. cyt., s. 420.

${ }^{16}$ Por. III Concilium Toletanum can. 16, Mansi IX 996, zob. aneks niżej.

${ }^{17}$ Por. IV Concilium Toletanum can. 29, Mansi X 627, zob. aneks niżej.

${ }^{18}$ Por. XII Concilium Toletanum can. 11, Mansi XI 1037-1038, zob. aneks niżej.

19 Por. XVI Concilium Toletanum can. 2, Mansi XII 69-70, zob. aneks niżej.

${ }^{20}$ Por. IV Concilium Toletanum can. 29. 
cych pochodnie ${ }^{21}$. Wskazane praktyki zdają się wskazywać, że na terenach Hiszpanii i Galii, wielu ludzi związanych było $\mathrm{z}$ religiami naturalnymi, nazywanych też religiami niskimi ${ }^{22}$, których charakterystycznym wyrazem jest kult sił przyrody, świętych gajów, źródeł itp. Ciekawe, że uchwały synodalne nie wspominają ani stowem o kulcie bóstw pogańskich, tzn. o przykładach religii wysokiej, o której mówią w swoich kazaniach tak św. Cezary z Arles jak i bliższy w czasie i miejscu synodom w Toledo św. Marcin z Bragi. Czyżby więc w na przełomie VI i VII wieku kult ten był nieobecny? Postawienie takiej tezy nie jest możliwe, tym bardziej, że ustawodawca posługuje się językiem bardzo ogólnym. Używając sformułowań: „wielbiciele idoli, czyniący wiele innych rzeczy, o których długo by opowiadać" ${ }^{23}$, wskazuje jednoznacznie, że problem jest poważny, a zakres kultu szeroki. Możemy więc domniemywać, powołując się także na nauczanie św. Cezarego z Arles i św. Marcina z Bragi, że uchwały synodalne $w$ swojej treści obejmują $z$ całą pewnością również kult bóstw osobowych, zapożyczonych z panteonu rzymskiego czy też germańskiego.

1. Bałwochwalcy. $Z$ treści kanonów wynika jednoznacznie, że grzech bałwochwalstwa był popełniany przede wszystkim przez przedstawicieli najnizszych warstw społecznych, głównie ze środowisk wiejskich, gdzie chrześcijaństwo jeszcze się nie ugruntowało ${ }^{24}$. Ale przypadki bałwochwalstwa można było spotkać również pośród właścicieli ziemskich, a nawet duchownych, którym popełnianie tego grzechu zarzucono wprost na IV synodzie w Toledo. Synod potępił wówczas tych biskupów, prezbiterów, diakonów oraz innych duchownych niższych święceniami, którzy zwracali się po radę do magów, jasnowidzów czy też wróżbitów. Jednocześnie ojcowie synodalni przypomnieli, że zadaniem biskupów jest nauczanie wiernych, stąd powinni oni znać Pismo św. oraz uchwały synodalne ${ }^{25}$. Omawiane przez nas synody karciły biskupów przede wszystkim $\mathrm{z}$ tytułu opieszałości lub zbytniej pobłażliwości w walce $\mathrm{z}$ bałwochwalstwem. Zarzut ten powtarza się w uchwałach synodów III, XII i XVI. Zdaniem ustawodawcy brak gorliwości biskupów w walce $z$ bałwochwalstwem był dużym przewinieniem przyczyniającym się do utrwalenia, a nawet rozszerzania zwyczajów pogańskich wśród wiernych. Na zbytnią pobłażliwość biskupów wskazywal także Tomus, tj. dokument, który król Erwig przedstawił na początku obrad XII synodu w Toledo ${ }^{26}$.

${ }^{21}$ Por. XII Concilium Toletanum can. 11 i XVI Concilium Toletanum can. 2.

22 Por. M. Olszewski, Pogaństwo i zabobon, „Znak” 50 (1998) nr 515, 79.

23 Por. XVI Concilium Toletanum can. 2, zob. aneks niżej.

24 Por. J. Orlandis, Los concilios, dz. cyt., s. 420-421.

25 Por. IV Concilium Toletanum can. 25, Mansi X 626-627. VIII synod w Toledo zobowiązal duchownych do znajomości Psalterza, podstawowych kanonów synodalnych oraz formuły chrzcielnej. Ustalenia te wskazują na bardzo niski poziom przygotowania duchowieństwa do wypehniania swoich obowiązków, zob. także P.C. Díaz - J.M. Torres, dz. cyt., s. 252. 
2. Bałwochwalstwo świętokradztwem. Bałwochwalstwo uważane było za jeden $\mathrm{z}$ najcięższych grzechów. Ustawodawcy chcąc ukazać ogrom jego zła, używali w przyjętych kanonach odpowiednio dobranej terminologii: świętokradztwo (sacrilegium) ${ }^{27}$, zbrodnia (crimen) ${ }^{28}$, bezbożność, nieprawość (nefas $)^{29}$. Stosowanie takiej terminologii nie było nowością: odnajdziemy ją w pismach wielu pisarzy chrześcijańskich, np. Tertuliana ${ }^{30}$, Maksyma $z$ Tury$\mathrm{nu}^{31}$, czy też w uchwałach wcześniejszych synodów, np. synodu w Elwirze (crimen principale) $^{32}$. Ponadto ojcowie XVI synodu w Toledo wyraźnie odróżnili grzech bałwochwalstwa od osoby grzesznika. Grzech należy potępić, grzesznika natomiast „wyrwać spod władzy [diabła] i przywrócić Stwórcy”33. Sformułowania te nie oznaczały bynajmniej pobłażania wobec winnego. Uchwały synodalne przewidywały bowiem również kary za popełniony grzech bałwochwalstwa.

3. Biblijne podstawy do walki $\mathrm{z}$ balwochwalstwem. Kanony dotyczące bałwochwalstwa ustalone na III i IV synodzie w Toledo mają charakter ściśle normatywny. Ustawodawca nie przedstawił żadnej argumentacji o charakterze teologicznym, a raczej bazował na oczywistym przekonaniu o ciężkości grzechu bałwochwalstwa, wyraźnie wskazanej w uchwałach wcześniejszych synodów i nauczaniu Ojców Kościoła. Dopiero kolejne synody XII i XVI posłużyły się argumentami biblijnymi. Czy na takie sformułowanie kanonów miały wpływ zauważalne tendencje podniesienia poziomu intelektualnego i moralnego duchowieństwa, trudno powiedzieć ${ }^{34}$. Ojcowie synodalni formułując treść kanonów o bałwochwalstwie sięgnęli do odpowiednio dobranych tekstów biblijnych, zaczerpniętych tak ze Starego jak i z Nowego Testamentu. Dosłownie cytowane są fragmenty z Księgi Wyjścia 20, 4; 22, 19, z Księgi Powtórzonego Prawa 6, 13 oraz 17, 2-5, z Księgi Kapłańskiej 26, 1, a spośród tekstów Nowego Testa-

${ }^{26}$ Erwig w Tomus zwrócił uwagę, że na rozwój bałwochwalstwa wśród ludności wiejskiej miała poważny wpływ bardzo słabo rozwinięta organizacja kościelna. Jego zdaniem z tego powodu wiele obszarów pozostawało poza zasięgiem oddziaływania Kościoła, por. P.C. Díaz - J.M. Torres, dz. cyt., s. 251.

${ }^{27}$ Por. IV Concilium Toletanum can. 29, Mansi X 627; XII Concilium Toletanum can. $11 ;$ XVI Concilium Toletanum can. 2.

${ }^{28}$ Por. XVI Concilium Toletanum can. 2.

29 Por. XII Concilium Toletanum can. 11.

${ }^{30}$ Por. De idololatria 1, CSEL 20, 31, CCL 2, 1101.

${ }^{31}$ Por. Sermo 30, 3, CCL 23, 118.

32 Por. Concilium Eliberitanum can. 1, Mansi II 5-6. W kodeksie Emilianense pojawia się w tym miejscu nieco inny termin: „crimen capitale”. Kwalifikacja moralna pozostaje jednak taka sama, por. Concilios Visigóticos e Hispano-Romanos. Edición preparada por J. Vives con la colaboración de T. Marín Martínez y G. Martínez Díez, Barcelona - Madrid 1963, 2.

${ }^{33}$ XVI Concilium Toletanum can. 2, zob. aneks niżej.

34 Por. III Concilium Toletanum can. 7, Mansi IX 994; IV Concilium Toletanum can. 24 i 25, Mansi X 626-627; XI Concilium Toletanum can. 2 i 10, Mansi XI 143. 
mentu uczestnicy XII synodu w Toledo posłużyli się zdaniem z Apokalipsy św. Jana 6, 8, zaś zgromadzeni na XVI synodzie odwołali się do nauczania zawartego w Pierwszym Liście św. Piotra 5, 8-9. W tym przypadku jednak w redakcji kanonu nie zamieścili dokładnego cytatu, a jedynie przytoczyli streszczenie myśli autora listu ${ }^{35}$. Cytowane fragmenty z ksiąg Starego Testamentu wskazywały na Boże przykazanie zakazujące kultu bóstw pogańskich, sił przyrody czy też wytworów ludzkiej pracy. Natomiast wspomniane fragmenty Nowego Testamentu ukazywały działanie diabła, który jest śmiercią (Ap 6,8), i który stoi za każdym grzechem bałwochwalstwa. Autorzy kanonów uważali, że niemądrzy ludzie dali się oszukać diabłu, który ,posługując się różnymi podstępami i oszustwami, zwodząc [...], nie przestaje chwytać ich w swoje sidła"36. Tak oszukani stali się ,,wielbicielami idoli, czcicielami kamieni, palącymi pochodnie, czczącymi święte źródła i drzewa, wróżbitami oraz czarodziejami"37. Wszystko to uznawane było jako wyraz kultu diabła. Takie sformulowania zawarte w redakcji kanonu miały przede wszystkim przestrzec przed praktykowaniem bałwochwalstwa, które niechybnie prowadzi do śmierci wiecznej. Nauka ta wypracowana przez św. Pawła ${ }^{38}$, została następnie przejęta i rozbudowana przez wielu starożytnych autorów, np. Tertuliana ${ }^{39}$, św. Maksyma z Turynu ${ }^{40}$, św. Augustyna ${ }^{41}$, czy św. Cezarego z Arles ${ }^{42}$.

4. Kary za grzech bałwochwalstwa. Ojcowie synodalni do wszelkich pozostałości kultów i praktyk pogańskich odnosili się $\mathrm{z}$ wielką surowością. Wymagano więc zniszczenia wszystkiego, co miało jakikolwiek związek z idolatrią. W postanowieniach XII synodu w Toledo czytamy: „każda ofiara bałwochwalcza i wszelka rzecz przeciwko świętej wierze, które ludzie glupi i zniewoleni przez kult diabła praktykują, mają być [...] jako świętokradztwo wytropione i wyrwane z korzeniami, a wyrwane - unicestwione"43. Odpowiedzialnymi za walkę $\mathrm{z}$ bałwochwalstwem byli biskupi oraz specjalnie wyznaczeni sędziowie. Według wskazań III synodu byli to iudices territori ${ }^{44}$. Byli oni zobowiązani nie tylko do sądzenia bałwochwalców, ale również do prowadzenia ich poszukiwań. Kary za bałwochwalstwo nie były łagodne, choć $\mathrm{z}$ góry wykluczono karę śmierci ${ }^{45}$. Przewidywane kary były zróżnicowane i zależały od stopnia zaangażowania,

\footnotetext{
${ }^{35}$ Por. XVI Concilium Toletanum can. 2.

36 Tamże, Mansi XII 69-70, zob. aneks niżej.

37 Tamże, zob. aneks niżej.

38 Por. 1 Kor $8,4-5 ; 10,19-21$.

39 Por. De spectaculis 4, CSEL 20, 6, lub CCL 1, 231.

40 Por. Sermo 107, 2, CCL 23, 420.

41 Por. De doctrina christiana II 36, CCL 32, 58-59.

42 Por. Sermo 53, 1, CCL 103, 233-234.

${ }^{43}$ XII Concilium Toletanum can. 11, Mansi XI 1037-1038.

44 III Concilium Toletanum can. 16, Mansi IX 996.

${ }^{45}$ Por. XII Concilium Toletanum can. 11.
} 
a także od statusu społecznego winnego. Duchowni, których przyłapano na radzeniu się czarowników, jasnowidzów lub wróźbitów byli, zgodnie z ustaleniami 29 kanonu IV synodu w Toledo, skazywani na dożywotnią pokutę w klasztorze bez żadnej możliwości powrotu do wypełniania swojej posługi. W intencji prawodawcy miał to być czas płaczu za popelniony grzech świętokradztwa $^{46}$. Oprócz odosobnienia w klasztorze duchowny taki był pozbawiany wszelkich godności. Kanon nie określa, czy skazani mogli w czasie trwania pokuty sprawować funkcje wynikające z przyjętych święceń. Należy jednak na podstawie przyjętej wówczas dyscypliny kościelnej uznać, że było to niemożli$\mathrm{we}^{47}$. Niewolnicy przyłapani na bałwochwalstwie byli karani chlostą ${ }^{48}$, zakuwani w kajdany i przekazywani pod dozór swoich wlaścicieli. Ci zaś pod przysięgą musieli zobowiązać się, iż dopilnują swoich podwładnych, aby nigdy nie popełniali już podobnych przewinień. Mając doświadczenie różnych zachowań właścicieli, bądź też przewidując pewne trudności, XII synod ustalił, że gdyby nie chcieli złożyć takiej przysięgi, słudzy i poddani winni grzechu bałwochwalstwa będą zdani na laskę królewską ${ }^{49}$. Król mógł ich przekazać na własność innemu panu, który zapewne musial jednak zagwarantować wprowadzenie skuteczniejszych środków do walki z praktykami pogańskimi poddanych mu shug ${ }^{50}$. Surowsze kary czekały osoby wolne. Wobec nich tenże sam synod orzekt: „niech otrzymają wyrok wiecznej ekskomuniki i karę surowego wygnania"51.

Osobne kary przewidziano dla zaniedbujących walkę $\mathrm{z}$ bałwochwalstwem, a także ociągających się ze wspólpracą z wymiarem sprawiedliwości. Karani byli więc duchowni oraz sędziowie, którzy wiedząc o praktykowaniu bałwochwalstwa na podległym im terenie, nie podejmowali stosownych działań, lekceważąc tym samym powagę sytuacji i panoszące się zło. W takim wypadku uchwały XVI synodu w Toledo przewidywały pozbawienie piastowanego urzędu oraz konieczność odbycia pokuty trwającej przez jeden rok. Po odbyciu kary mogli oni powrócić na wcześniej zajmowany urząd ${ }^{52}$. Za winnych współudziału w grzechu bałwochwalstwa uznawano również właścicieli, którzy wiedząc o postępowaniu swoich poddanych, wstrzymywali się od reakcji. Pogląd taki można spotkać już w uchwałach III synodu ${ }^{53}$, jak również w wypowiedziach

\footnotetext{
${ }^{46}$ Por. A. De Mier Vélez, Supersticiones y horóscopos entre los cristianos visigodos y francos, „Religión y Cultura” 41 (1995) 827.

${ }^{47}$ II Synod w Bradze w kanonie 37 zakazał ekskomunikowanym duchownym sprawowania jakichkolwiek funkcji wynikających z przyjętych święceń.

${ }^{48}$ Sw. Grzegorz Wielki w Liście do Januariusza, biskupa Sardynii poleca mu, aby niewolników czczących bałwany, którzy nie chcą się poprawić, karać chłostą, por. Epistolae IX 205, CCL 140A, 764.

${ }^{49}$ XII Concilium Toletanum can. 11.

${ }^{50}$ Por. J. Orlandis, Los concilios., dz. cyt., s. 421.

51 XII Concilium Toletanum can. 11, Mansi XI 1037-1038.

52 Por. XVI Concilium Toletanum can. 2.

${ }^{53}$ Por. III Concilium Toletanum can. 16.
} 
niektórych Ojców Kościoła, np. św. Maksyma z Turynu, który nauczał, że każdy właściciel przymykający oko na bałwochwalcze praktyki swoich poddanych, faktycznie uczestniczy w ich grzechu ${ }^{54}$. Za takie zaniedbania synod przewidywał nałożenie na winnych ekskomuniki oraz pozbawienie wszelkich praw do sługi winnego grzechu bałwochwalstwa. Ustawodawca nie określił w tym przypadku czasu trwania kary ekskomuniki ${ }^{55}$.

Wszystkie te postanowienia miały z pewnością zmusić biskupów, sędziów oraz właścicieli ziemskich do bardziej radykalnych działań przeciwko praktykom bałwochwalstwa. Niestety przyjęte uchwały nie odniosły chyba zamierzonego skutku, a problem najprawdopodobniej musiał zaostrzyć się jeszcze bardziej, skoro było konieczne wprowadzenie jeszcze surowszych kar przez XVI synod. Tym razem wspomina się o osobach, które bronią bałwochwalców i w ten sposób przeciwstawiają się biskupom i sędziom. Za takie postępowanie synod nakładał na winnych ekskomunikę, a ponadto, jeśli pochodzili ze stanu szlacheckiego musieli zapłacić grzywnę o ściśle określonej wysokości. Natomiast jeśli byli osobami niższego stanu, otrzymywali karę chłosty stu uderzeń, golono im głowy oraz rekwirowano połowę majątku ${ }^{56}$.

Warto zatrzymać się jeszcze nad jednym przepisem wydanym na XVI synodzie w Toledo. Ustalono, że ofiary składane bałwanom powinny zostać przekazane najbliżej położonym kościołom. Powinno to się dokonać w obecności przyłapanych na grzechu bałwochwalstwa ${ }^{57}$. Być może, jak to sugeruje S. McKenna, podstawą tej uchwały była myśl św. Augustyna, który w liście do Publikoli w $398 \mathrm{r}$. pisał, że rzeczy będące przedmiotem kultu pogańskiego, można używać w kulcie prawdziwego Boga. Dokonuje się z nimi to samo, co dzieje się z człowiekiem, który porzuca bałwochwalstwo i zaczyna oddawać cześć jedynemu Bogu ${ }^{58}$. Podobny pogląd reprezentował także św. Grzegorz Wielki $^{59}$.

1. Fakt podejmowania przez synody w Toledo problemu bałwochwalstwa jednoznacznie wskazuje, iż mimo trwającej od zarania chrześcijaństwa chrystianizacji Półwyspu Iberyjskiego nadal żywe były praktyki i zwyczaje mające swój rodowód w pogaństwie. Trudno określić wielkość problemu i jego zasięg.

\footnotetext{
54 Por. Sermo 107, 1, CCL 23, 420.

55 Por. III Concilium Toletanum can. 16; XII Concilium Toletanum can. 11.

${ }^{56}$ Por. XVI Concilium Toletanum can. 2.

57 Por. J. Orlandis, Los concilios, dz. cyt., s. 487.

58 Por. S. McKenna, Paganism and pagan survivals in Spain up to the fall of the Visigothic Kingdom, Washington 1938, 133; zob. Augustinus, Epistula 47, 3, CSEL 34/2, 132.

59 Por. Epistolae XI 56, CCL 140A, 961.
} 
Powszechnie uważa się, że dotyczyl przede wszystkim słabo schrystianizowanej ludności wiejskiej oraz w dużo mniejszym stopniu przedstawicieli warstw wyższych, również kleru. Ze sformułowań kanonów można wysnuć kolejny wniosek, że równie poważnym problemem było słabe zaangażowanie się duchownych, sędziów i właścicieli ziemskich w walkę z tym grzechem. Prawdopodobnie powodem ich opieszałości był nie tylko brak gorliwości, ale również niewystarczająca świadomość powagi problemu oraz stabe przygotowanie do podjęcia odpowiednich działań.

2. Spośród omawianych kanonów na szczególną uwagę zasługują dwa, sformułowane na XII i XVI synodzie, ponieważ oprócz sformulowań ściśle prawnych, zawierają również część teologiczną. Ustawodawcy w redakcji tych kanonów odwołali się do prawa Bożego zawartego w Dekalogu. Wskazują również na skutki duchowe grzechu bałwochwalstwa, który według nich jest jednoznaczny $z$ kultem diabła i dlatego prowadzi człowieka do śmierci wiecznej. Takie sformułowanie kanonów miało prawdopodobnie uwrażliwić biskupów, sędziów, właścicieli ziemskich na wagą problemu i zachęcić ich do gorliwszych działań na rzecz duchowego dobra poddanych im wiernych.

3. Kary przewidziane za bałwochwalstwo były dość zróżnicowane. Ich wielkość zależała od stopnia udziału w kulcie idoli, a także od statusu społecznego winowajcy. Stosowano przede wszystkim karę ekskomuniki, czasem dożywotniej; dla duchownych karę pokuty odbywanej w klasztorze; dla innych kary banicji, chlosty czy grzywny.

4. Bez wątpienia ojcowie synodalni w przyjętych kanonach wykazali się nie tylko zmyslem prawnym, ale i pastoralnym. Zależało im przede wszystkim na zachowaniu czystości wiary oraz na doprowadzeniu wiernych do zbawienia.

\section{DIE VERDAMMNIS DES GÖTZENDIENSTES IN DEN SYNODEN IN TOLEDO 6-7. JAHRHUNDERT}

\section{(Zusammenfassung)}

Das Ziel des Artikels ist die Darstellung und Analyse der Synodenbeschlüsse in Toledo im 6. und 7. Jahrhundert, die sich vor allem auf den unter der bäuerlichen Bevölkerung verbreitenden Götzendienst bezogen haben. Bestimmte Formen des Götzendienstes konnte man auch unter den höheren Schichten, wie etwa den Geistlichen, beobachten. Die Synodenväter verurteilten nicht nur die Götzendienstpraktiken an sich, sondern auch all jene, die nicht eifrig genug gegen sie ankämpften. In ihren Beschlüssen beriefen sie sich auf die Heilige Schrift, aber auch auf die Lehre der Kirchenväter und der früheren Synoden. Die verfassten Beschlüsse weisen eindeutig darauf hin, dass ihr oberstes Ziel die Sorge um die Unverfälschbarkeit des Glaubens und den Heil der Gläubigen war. 


\section{Aneks \\ KANONY III, IV, XII I XVI SYNODU W TOLEDO DOTYCZĄCE BAEWOCHWALSTWA}

\section{Synod w Toledo - 589 r.}

Kanon 16. Aby biskupi wraz z sędziami niszczyli batwany $i$ aby panowie zabraniali swoim stugom czcić batwany

$\mathrm{Z}$ powodu rozpowszechnienia w prawie całej Hiszpanii i Galii świętokradczego bałwochwalstwa, za zgodą prześwietnego króla, nakazał święty synod, co następuje: Każdy biskup w swojej diecezji wspólnie z sędzią rejonowym, przeprowadzi bardzo skrupulatne dochodzenie w sprawie wspomnianego świętokradztwa. Bez zwłoki niech zniszczą wszystko, co napotkają, a trwającym w tym błędzie ocalą życie nakładając na nich odpowiednie kary. A jeśli zaniedbają takiego postępowania, niech wiedzą obaj, tak biskup jak i sędzia, że zaciągają karę ekskomuniki. Jeśli jacyś właściciele ziemscy zaniedbaliby wykorzenienia tego grzechu w swoich posiadłościach i nie chcieliby zabronić popełniania go swoim sługom, niech także oni będą przez biskupa wyłączeni z jedności ${ }^{1}$.

\section{Synod w Toledo - 633 r.}

Kanon 29. O duchownych radzacych się magów $i$ wróżbitów

Gdyby zauważono, że jakiś biskup, prezbiter, diakon lub jakikolwiek inny duchowny zasięgał rady magów, czarowników, wróżbitów, jasnowidzów, albo innych zajmujących się wiedzą tajemną czy wykonujących podobne praktyki, niech pozbawiony wszelkich zaszczytnych godności zostanie zamknięty w klasztorze, gdzie oddany ciągłej pokucie ma opłakiwać popełnione zbrodnie świętokradztwa ${ }^{2}$.

\section{Synod w Toledo - 681 r.}

Kanon 11. $O$ czczqcych batwany

${ }^{1}$ Tłumaczenia dokonano na podstawie: Concilios visigóticos e hispano-romanos. Edición preparada por J. Vives con la colaboración de T. Marín Martínez, G. Martínez Díez, Barcelona, Madrid 1963. Jest to wydanie dwujęzyczne: hiszpańsko-łacińskie.

${ }^{2}$ Tamże s. 203. 
Oto są przykazania, które Pan powiedziak: „Nie będziesz czynil żadnej rzeźby ani żadnego obrazu tego, co jest na niebie wysoko, ani tego, co jest na ziemi nisko, ani tego, co jest w wodach pod ziemią! Nie będziesz oddawał im pokłonu i nie będziesz im służył” (Wj 20,5), a także: „kto składa ofiary bożkom z wyjątkiem samego Pana, umrze” (Wj 22, 19). I w innym miejscu zaś: „Mężczyzna lub kobieta, ktoś kto czynić będzie to, co jest złe w oczach Pana, Boga twego, przestępując Jego przymierze, przechodząc do bogów obcych, by służyć im i oddawać pokłon, jak słońcu, księżycowi lub całemu wojsku niebieskiemu, czego nie nakazalem - skoro ci to zostanie doniesione, wysłuchasz i zbadasz dokladnie sprawę. Jeśli okaże się prawdą, że taką ohydę popełniono w Izraelu, zaprowadzisz tego mężczyznę lub kobietę - którzy tej złej rzeczy się dopuścili do bramy miasta i będziesz tego mężczyznę lub tę kobietę kamienowal" (Pwt 17, 2-5). Przypominamy przykazania Pana, nie dla ukarania, ale dla odstraszenia winnych. Nie ogłaszamy dla nich wyroku śmierci, ale upominamy czczących bałwany, adorujących kamienie, zapalających pochodnie oraz czczących źródła i drzewa, aby dostrzegli, że sami dobrowolnie skazują się na śmierć jako ci, którzy składają ofiary diabłu. Wszak diabeł nosi imię śmierci zgodnie z tym, co jest o nim napisane: I bylo jego imię śmierć (por. Ap 6,8). Przeto każda ofiara bałwochwalcza i wszelka rzecz przeciwko świętej wierze, które ludzie głupi i zniewoleni przez kult diabła praktykują, mają być na żądanie biskupa lub sędziego jako świętokradztwo wytropione i wyrwane $\mathrm{z}$ korzeniami, a wyrwane - unicestwione. Tych zaś, którzy dopuszczają się takiej okropności, niech ukarzą chłostą i zakutych w kajdany oddadzą ich panom. Będzie to możliwe tylko wtedy, gdy ich właściciele przysięgną, że będą czuwać nad nimi $z$ tak wielką gorliwością, iż nie będą mogli w przyszłości popełnić podobnego przestępstwa. W przypadku, gdyby właściciele nie chcieli przyjąć wspomnianych winowajców pod swoją opiekę, ci, którzy nałożyli na nich karę, niech postawią ich przed królem, aby władza królewska zyskała możliwość ich ułaskawienia. Właściciele, którzy zostali poinformowani o błędach swoich sług i odroczyli nałożenie kary, niech cierpią karę ekskomuniki. Niech mają także świadomość, że utracili wszelkie prawa do sługi, którego nie chcieli ukarać. Jeśli zaś zamieszani w te błędy byliby przypadkiem osobami wolnymi, niech otrzymają wyrok wiecznej ekskomuniki $i$ karę surowego wygnania ${ }^{3}$.

\section{Synod w Toledo - 693 r.}

\section{Kanon 2. O czcicielach batwanów}

Jest rzeczą oczywistą, że nieprzyjaciel rodzaju ludzkiego, jak naucza Apostol, biegnie przez świat rycząc i szukając kogo pożreć (por. 1P 5, 8-9), posługując się różnymi podstępami i oszustwami, zwodząc wielu niemądrych ludzi, nie przestaje chwytać ich w swoje sidla; i chociaż Pan nakazuje, abyś nie czynił żadnej rzeźby ani żadnego obrazu tego co jest w górze w niebie, ani tego co jest na dole, na ziemi (Wj 20,4), itd., a w innym miejscu powiada: „Nie będziecie czynić bałwanów ani rzeźb, nie będziecie wznosić sanktuariów, nie położycie kamienia... aby go czcić $(\mathrm{Kpł} 26,1)$,

\footnotetext{
${ }^{3}$ Tamże s. 398-399.
} 
zaś nieco dalej: Będziesz czcił Pana Boga swego i tylko Jemu będziesz służyl" (por. Pwt 6,13), to jednak oni, oszukani przez różne namowy, stają się wielbicielami idoli, czcicielami kamieni, palącymi pochodnie, czczącymi święte źródła i drzewa, wróżbitami oraz czarodziejami, a także czynią wiele innych rzeczy, o których dhugo by opowiadać. Ponieważ diabeł nie jest ani ich Stwórcą, ani ich Panem, ani ich Odkupicielem wypada, aby przełożeni kościołów Bożych, czuwali z największą uwagą, by tych, których nieprzyjaciel zgubną namową usidlił i sprawił, że popełnili różne świętokradztwa, wyrwać spod jego władzy i przywrócić ich Stwórcy.

Liczne edykty świętych Ojców, ogłoszone na różnych synodach, dowodzą konieczności wykorzenienia tych świętokradztw. Przejrzeliśmy je uważnie oraz zbadaliśmy ich ustalenia $\mathrm{z}$ przenikliwością i powagą. A ponieważ są bardzo sluszne, postanawiamy za zgodą i gorącym nakazem najpobożniejszego pana naszego króla Egiki ${ }^{4}$, by wszyscy biskupi i prezbiterzy, a także przewodzący postępowaniom sądowym, przestrzegali ich z największą gorliwością. Gdziekolwiek napotkaliby czczących lub praktykujących omawiane świętokradztwa, lub jakiekolwiek inne rzeczy zabronione przez prawo Boże albo zakazane przez postanowienia świętych Ojców, niezależnie od pochodzenia lub stanu tych osób, trzymając się treści odpowiednich wskazań, niech nie zwlekają w ich karaniu i wyplenianiu. Ponadto wszystko, co na miejscu świętokradztwa miało być złożone w ofierze, niech będzie oddane do sąsiednich kościołów, w obecności tych, którzy chcieli je złożyć w świętokradczym darze.

Jeśli biskup, prezbiter albo sędzia, dysponując pewną i niepodważalną wiedzą o zbrodni jakiegokolwiek świętokradztwa, popełnioną na miejscu podległemu jego jurysdykcji, zaniedbałby natychmiastowe napomnienie, zostanie pozbawiony swego urzędu i niech będzie poddany pokucie przez okres jednego roku, po której powróci na swój urząd. $\mathrm{Na}$ czas, w którym winny będzie pozbawiony urzędu, książę ma obowiązek wyznaczyć na urząd kogoś pełnego bojaźni Bożej, i jak Finees (por. $1 \mathrm{Mch} 2$ 2, 26. 54) płonącego żarliwością duchową. Powinien on razem $\mathrm{z}$ sędziami, zgodnie z tym co powiedzieliśmy, gdziekolwiek zauważy świętokradztwo, na wszelki sposób je wykorzenić i w ten sposób powstrzymać gniew Pański wobec całego ludu. A jeśli ktoś w obronie takich osób będzie się przeciwstawiał biskupom lub sędziom, uniemożliwiając im napomnienie winnych lub wykorzenienie świętokradztwa, co należy do ich obowiązków, i nie zacznie współpracować z osobami, które badają owe sprawy i unicestwiają tak wielkie zło, niech będzie oblożony ekskomuniką w obliczu niepodzielnej Trójcy. Ponadto, jeśli bylby osobą szlachetnego rodu, zapłaci trzy libry złota do skarbca kościelnego. Gdyby zaś był osobą niższego stanu, otrzyma chłostę stu uderzeń, na hańbę zostanie ogolony i będzie ukarany przepadkiem połowy majątku na rzecz skarbu.

\footnotetext{
${ }^{4}$ Egika, król wizygocki panujący w latach $687-702$.

5 Tamże s. 498-500.
} 